\title{
Analysis of Technology Acceptance in Student Entrepreneurs
}

\author{
Ahmad Sehabuddin ${ }^{1}$, Ubaedul Mustofa ${ }^{2}$ \\ \{acmadin@mail.unnes.ac.id ${ }^{1}$, ubaed_almustafa@mail.unnes.ac.id $\left.{ }^{2}\right\}$ \\ Universitas Negeri Semarang, Indonesia ${ }^{1,2}$
}

\begin{abstract}
This study aims to analyze the acceptance of technology in entrepreneurship. This research adopts the TAM theory and the TRA theory. In TAM theory adopts two variables are perceived usefulness and perceived ease of use. Meanwhile, the TRA theory adopt an attitude. This research is a quantitative study. The sample in this study was Semarang State University students who joined in the Indonesian Young Entrepreneurs Association. Sampling techniques in this study using the formula from Slovin. Analysis techniques were use SEM with the WarpPLS 7.0 application. The results of this study are the perceived usefulness and perceived ease of use have a positive and significant effect directly on attitudes to using technology in entrepreneurship. Perceived ease of use has a positive and significant effect directly on perceived usefulness. On the other hand, perceived ease of use has an indirect positive and significant effect on attitudes to using technology in entrepreneurship through perceived usefulness. The conclusion of this research is that perceived usefulness and perceived convenience have a positive effect on students' attitudes in applying technology when entrepreneurship. It's means that the application of technology in student entrepreneurship is responded positively.
\end{abstract}

Keywords: Entrepreneurship, Student, TAM, TRA

\section{Introduction}

In this era, technology encourages various innovations for every aspect of community life in terms of economic, social, cultural and technological issues. Technology will change people's lifestyles and put pressure on society if they are unable to improve with the environment. Individuals who are unable to cope with these eras will have the negative impacts of their social life.

Technology has become a necessity for the community and inseparable in meeting the needs of information and communication media. The use of technology in entrepreneurship will also have a positive effect when squeezed by distance and time. Technology will provide convenience and benefits for users in entrepreneurship. Wang et al. [1] the consequence of this is the high acceptance of the technology. The existence of usefulness and ease of use felt by someone in using technology will have an impact on the high public interest in using technology. Rosen et al. [2] also stated that new technology is needed in the commercial. The purpose of using new technology in the commercial is to dominate market share, facilitate transactions and business more effectively and efficiently.

The use of technology for students in conducting entrepreneurial transactions will provide major changes in aspects of the ability to adopt technology, the ability to compete, and the ability to develop technology in entrepreneurship. The use of technology, such as e-commerce and e- 
marketing is international markets access. It's means that using technology here will have a positive impact on business progress in the international market. By utilizing technology, it will be able to compete with other entrepreneurs [3][4].

Theory of Technology Acceptance Model (TAM) is a model used to determine the acceptance of technology and information systems. Davis [5] in his research combines TAM with Theory of Reasoned Action (TRA) and many researchers have indicated that this model is suitable for technology adoption [6][7][8]. Davis et al. [9], the main purpose of TAM is to provide a basis for tracing the influence of external factors on user beliefs, attitudes, and goals. TAM considers that two individual views, perceived usefulness (PU) and perceived ease of use (PEOU) are the main influences on computer acceptance behaviour.

Perceived usefulness is a key variable for predicting consumer acceptance of continued intentions using technology [10]. Besides that, attitudes are predicted by perceived benefit [11]. From some of the results of these studies, it can be concluded that the perception of usefulness plays a more influential role in shaping the attitude of technology use [12].

Liou et al. [13] found that perceived ease of use will have an impact on a person's attitude. Perceived ease of use technology will attract users in using these services. Idea of someone who wants easy access to information, especially in business, will encourage to use technology.

Online business is one business that adopts technology because of the convenience provided. Time and mobility are the reasons some people prefer to make purchases through the online system. The present of new technology can cause a reaction in users, both accepting and rejecting reactions.

Theory of reasoned action was developed by Fishbein and Ajzen [14]. This theory is derived from previous studies that began from the theory of attitude (theory of attitude) which studies about attitudes and behaviour (behaviour). Attitude arise because of positive beliefs or perceptions so that someone will take action according to the results that will be obtained. Hajer and Habib [15] to defined attitude is things that someone does because they have been done before. People will act because they have done the same thing. Attitudes that do it continuously will give birth to behavior. In using technology, the attitude in using technology is influenced by perceived usefulness and perceived ease of use.

Several studies show differences in research results related to technology acceptance. In other words, there is a research gap between one researcher and another. According to Juhri \& Dewi [16]; Mubiyantoro [17]; Kanchanatanee et al. [18]; Soroa-Koury \& Yang [19]; Yang et al. [20] stated that perceived usefulness does not significantly influence the attitude of using technology. Furthermore, Moses et al. [21] perceptions of ease have no significant effect perceived from the use of the attitude of teachers to use technology. But, study by Rizwan et al. [22] states that perceived usefulness and perceived ease of use have a positive effect on consumer attitudes online shopping. This means that consumers will be interested in using technology on online shopping. Furthermore, Anton et al. [23] succeeded in proving that perceived usefulness, and perceived ease of use influence to attitudes using e-readers.

The importance of this research is providing information that through this research, entrepreneurs who collaborate with technology can exist in business. Besides, it also aims to analyze the condition of individual psychology (perceived usefulness and perceived convenience) will influence the attitude of the use of technology in entrepreneurship. Therefore, we need awareness and education about the use of technology for students in entrepreneurship.

Therefore, this research needs to be done to find out the technology acceptance model of students in entrepreneurship. New technology usually faces challenges to be accepted by consumers. Because of the unique features of modern technology, it requires certain approaches to develop its acceptance. 


\section{Literature Review}

\subsection{Technology Acceptance Model Theory}

TAM was first introduced by Davis [5] which was developed based on the theory of reasoned Action model which is devoted to modeling user acceptance of information technology. TAM explains that the level of acceptance of information technology is determined by six factors, namely external variables, user perceptions of ease of use of technology (perceived ease of use), user perceptions of technology usability (perceived usefulness), user attitudes toward technology (attitude toward using), the tendency of user behavior to use technology (behavioral intention) and actual usage. External variables will directly affect the perceived usefulness and perceived convenience of the users. External variables related to system characteristics, development process and training [5].

Davis et al. [9] main objective of TAM is to provide a basis for tracing the influence of external factors on user beliefs, attitudes, and goals. TAM considers that 2 individual beliefs, namely perceived usefulness (PU) and perceived ease of use (PEOU) are the main influences for computer acceptance behavior.

Furthermore, in the TAM theory, perceived ease of use has a contribution to perceived usefulness. The less effort consumers feel in using the system allows consumers to get more work done [9]. Perceived ease of use has a positive and significant effect on perceived usefulness [22]. In the TAM theory it is said that perceived usefulness and perceived ease of use are important factors that influence consumer attitudes towards their interests and use of information systems [9].

\subsection{Theory of Reasoned Action}

The theory of reasoned action (Theory of Reasoned Action) was developed by Ajzen and Fishbein. This theory is derived from previous studies starting from the theory of attitude which studies attitudes and behavior. Theory of Reasoned Action (TRA) by Fishbein and Ajzen [24] was born of this theory due to the lack of success of studies examining attitude theory, namely the relationship between attitudes and behavior. The reasoned action (TRA) model by Fishbein and Ajzen [24] is a popular intention model that can be used to study behavioral intention with respect to the acceptance or use of technology.

Several research results regarding attitudes in the TAM construct state that attitude is an important factor influencing the behavior of users' adoption intentions of new technology. Furthermore, the perception of user usefulness has a positive and significant effect on personalization on the attitudes of business people [25].

\subsection{Perceived Usefulness}

Perceived usefulness is defined as the degree to which a person believes that using a particular system would enhance his or her job performance. Perceived ease of use, in contrast, refers to the degree to which a person believes that using a particular system would be free of effort [5] which means that perceived benefits are defined as the extent to which a person believes that using a particular system will improve performance. his job. Besides that, attitudes are predicted by perceived benefits [11]. From some of the results of these studies, it can be concluded that it is perceived usefulness that plays a stronger role in shaping attitudes to technology use [12]. 


\subsection{Perceived Ease of Use}

Perceived ease of use is the degree to which a person believes that using a particular system would be free of effort [5]. In the technological context, perceived ease of use is essential to influence perceived benefits and attitudes towards the use of e-learning 2.0 [26]. A research done by Moslehpour et al. [27] perceived ease of use as the variable with the strongest influence on behavioral intention. Another influence that perceived convenience exerts is on attitude. Teo $\&$ Noyes [28] state that perceived ease of play has a positive and significant influence to shape user attitudes. Same results were also presented by Elkaseh et al. [29] stated that the variable perceived ease of use has a contribution to affect user attitudes.

\subsection{Attitude}

Attitude is a form of someone's action that arises because of the trust factor. Jogiyanto [30] explains that attitudes arise because of someone's consideration in doing something. There are two considerations, namely the positive impact and the negative impact if you carry out activities. If someone has a positive perception, that person will act. However, if the impact is negative someone will think back and tend not to do. In using technology, consideration of positive and negative impacts is very sensitive for someone when using technology. Fisbhein \& Ajzen [14] explained that attitudes are determined by individual beliefs about the consequences of presenting a behavior (behavioral beliefs) and weighed based on the results of the evaluation of the consequences (outcome evaluation).

In attitude, there are three important components are affective, cognitive and conative. Affective means a certain feeling or judgment about an object, person, issue or event. Cognitive consists of knowledge, opinion and belief in an object. While the conative component is a form of feeling and evaluative [14].

The attitude of using technology depends on perceived ease of use, perceived usefulness. Someone will to consider it. If the use of technology has a value of benefits and ease of use for users, then a strong attitude will arise to use technology.

The research hypotheses:

Hypothesis 1: The attitude of using technology in entrepreneurial students has positively and significantly influenced by perceived usefulness

Hypothesis 2: Perceived ease of use has a positive and significant effect on the attitude of technology use in student entrepreneurship.

Hypothesis 3: Perceived ease of use has a positive and significant effect directly on perceived usefulness.

Hypothesis 4: Perceived ease of use has a positive and significant indirect effect on the attitude of using technology in entrepreneurship through perceived usefulness.

\section{Research Methods}

This research is a quantitative study that uses ex post facto. The population of the research was all students in Semarang State University who joined in the Indonesian Young Entrepreneurs Association. They are 243 students, and then 152 students were the samples taken by Slovin formula. This study uses a causality or influence model and to test the proposed hypothesis, the analysis technique used is SEM (Structural Equation Models) with an analysis tool using WarpPLS 7.0. 


\section{Result and Discussion}

Acceptance of technology in this study consisted of variables perceived ease of use, perceived usefulness and attitude to use technology. Respondents in this study amounted to 152 . However, 149 respondents filled out completely and 3 respondents who filled out incomplete.

Indicators to measure the construct of usability are faster completion of work, increasing performance, increasing productivity, increasing work effectiveness, facilitating work and being useful [5]. Perceived ease of use can be measured by indicators easy of learn, controllable, the interaction with a clear and understandable system, flexibility, easy to become skillful and easy to use [5]. Indicators in the attitude of the use of technology are good things, wise things, positive things and things that are liked [9][14]. The magnitude of the load loading factor for each indicator $>0.7$, this means that the indicators of each variable are feasible to be used in this study.

Table 1. Indicators Factor Loading

\begin{tabular}{cccc}
\hline Variable & Indicator & Factor loading & p-value \\
\hline & PU1 & 0.770 & $<0.001$ \\
PU2 & 0.832 & $<0.001$ \\
Perceived usefulness [5] & PU3 & 0.833 & $<0.001$ \\
& PU4 & 0.708 & $<0.001$ \\
& PU5 & 0.767 & $<0.001$ \\
& PU6 & 0.772 & $<0.001$ \\
\hline & PEOU1 & 0.722 & $<0.001$ \\
Perceived ease of use [5] & PEOU2 & 0.749 & $<0.001$ \\
& PEOU3 & 0.786 & $<0.001$ \\
& PEOU4 & 0.885 & $<0.001$ \\
& PEOU5 & 0.753 & $<0.001$ \\
& PEUO6 & 0.714 & $<0.001$ \\
\hline \multirow{4}{*}{ Attitudes using [9][14] } & ATT1 & 0.862 & $<0.001$ \\
& ATT2 & 0.704 & $<0.001$ \\
& ATT3 & 0.854 & $<0.001$ \\
& ATT4 & 0.753 & $<0.001$ \\
\hline
\end{tabular}

Output latent variable coefficient both variable perceived ease of use, perceived usefulness and attitudes using technology show valid, reliable and non-collinearity results. This means that the indicators forming each predictor variable can explain the response variable.

Table 2. Output Laten Variable Coefficient

\begin{tabular}{lccccc}
\hline & PU & PEOU & ATT & Criteria & Representation \\
\hline R- squared & 0.178 & & 0.545 & & \\
Composite reliable & 0.837 & 0.844 & 0.841 & $>0.70$ & Reliable \\
Cronbach's alpha & 0.723 & 0.788 & 0.735 & $>0.60$ & Reliable \\
Avg. var. extract & 0.521 & 0.632 & 0.527 & $>0.50$ & Valid \\
Full Collin. VIF & 1.690 & 1.458 & 2.075 & $<3.30$ & Non collinearity \\
Q-squared & & 0.181 & 0.540 & $>0.00$ & Valid \\
\hline
\end{tabular}


Model fit and quality indices display the results of several fit indicators. The results of each component fit and quality indices showed good and ideal results. This means that the model formed in this study is appropriate.

Table 3. Model fit and quality indices

\begin{tabular}{|c|c|c|c|}
\hline Model Fit and Quality Indices & Result & Fit criteria & Representation \\
\hline Average path coefficient (APC) & $\begin{array}{c}0.436 \\
(\mathrm{P}<0.001)\end{array}$ & $\mathrm{P}<0.05$ & Good \\
\hline Average R-squared (ARS) & $\begin{array}{c}0.362 \\
(\mathrm{P}<0.001)\end{array}$ & $\mathrm{P}<0.05$ & Good \\
\hline Average adjusted R-squared (AARS) & $\begin{array}{c}0.356 \\
(\mathrm{P}<0.001)\end{array}$ & $\mathrm{P}<0.05$ & Good \\
\hline Average block VIF (AVIF) & 1.158 & $\begin{array}{l}\text { acceptable if }<= \\
5, \text { ideally }<=3.3\end{array}$ & Ideal \\
\hline $\begin{array}{l}\text { Average full collinearity VIF } \\
\text { (AFVIF) }\end{array}$ & 1.741 & $\begin{array}{l}\text { acceptable if }<= \\
5, \text { ideally }<=3.3\end{array}$ & Ideal \\
\hline Tenenhaus GoF (GoF) & 0.360 & $\begin{array}{c}\text { small }>=0.1, \\
\text { medium }>=0.25, \\
\text { large }>=0.36\end{array}$ & Ideal \\
\hline Sympson's paradox ratio (SPR) & 1.000 & $\begin{array}{c}\text { acceptable if }>= \\
0.7, \text { ideally }=1\end{array}$ & Ideal \\
\hline R-squared contribution ratio (RSCR) & 1.000 & $\begin{array}{c}\text { acceptable if }>= \\
0.9, \text { ideally }=1\end{array}$ & Ideal \\
\hline Statistical suppression ratio (SSR) & 1.000 & $\begin{array}{c}\text { acceptable if }>= \\
0.7\end{array}$ & Ideal \\
\hline $\begin{array}{l}\text { Nonlinear bivariate causality direction } \\
\text { ratio (NLBCDR) }\end{array}$ & 1.000 & $\begin{array}{c}\text { acceptable if }>= \\
0.7\end{array}$ & Ideal \\
\hline
\end{tabular}

The results of hypothesis testing in the form of a path for each predictor variable and the response variable in model causality relationship bellow:

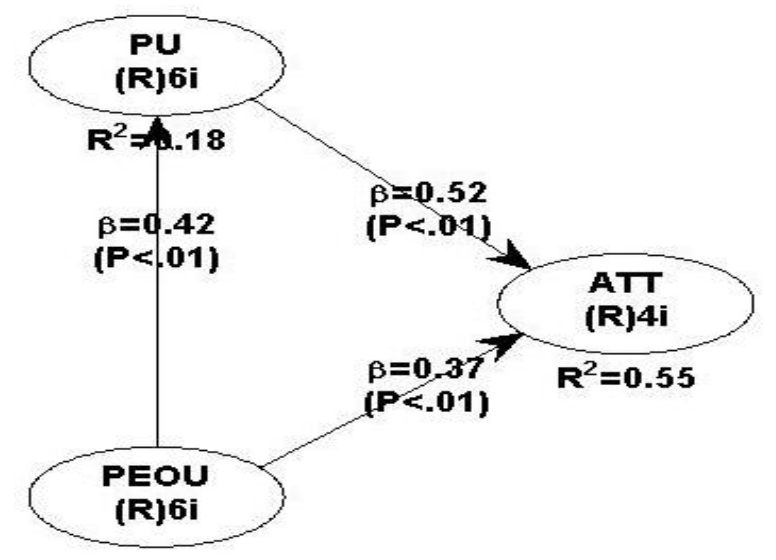

Fig. 1. Flowchart Causality Relationship. 


\subsection{Perceived usefulness has a positive and significant effect on the attitude of the use of technology student entrepreneurship}

Perceived usefulness is one of two basic determinants of predicting people's attitudes toward new systems or technologies, and people's attitudes towards brands [31][32].

This study found that perceived usefulness has a positive and significant effects on students' attitudes using technology. The path coefficient value is 0.52 with $\mathrm{p}$ value <.01. Perceived usefulness contributed positively to the attitudes of using technology in entrepreneurship by $33.6 \%$. The higher the perceived usefulness, the higher the contribution to the attitude of using technology in entrepreneurship.

Perceived usefulness as an important predictor that influences the attitude and acceptance of technology, the higher the perceived value, the more positive the attitude of someone towards the use of technology [33]. Besides, previous studies provide empirical evidence that there is a significant positive effect of perceived usefulness on the attitudes and intentions of using internet banking [34][35][36][37].

\subsection{Perceived ease of use has a positive and significant effect on the attitude of the use of technology student entrepreneurship}

Perceived ease of perceived use becomes a very important predictor, especially in the formation of positive attitudes towards users [38]. This research proves that perceived ease of use has a positive and significant effect on the attitude of technology use in student entrepreneurship. The path coefficient is 0.37 , with a p-value <.01. The amount of contribution of the influence of perceived ease of use on the attitude of the use of technology in entrepreneurship is $20.9 \%$. Perceived convenience has a smaller contribution value than the perceived usefulness to the attitude of using technology. This is due to the extrinsic aspects of technology users who prioritize the benefits to be gained from technology acceptance.

Furthermore, Guritno and Siringoringo [12] stated that perceived ease affects attitude even though the effect is smaller when compared to perceived usefulness towards attitude. From the other side Chen et al. [39] perceived ease of use has a greater impact in shaping the attitude of use where the significance and positive values are increasing in value.

Other studies have also concluded that perceived ease of use has a positive and significant influence on attitudes [40]. Perceived ease of use has a positive and significant effect on attitude [41]. Several other studies found that perceived ease of use does have a direct influence on attitudes in educational contexts [42].

\subsection{Perceived ease of use has a positive and significant effect on Perceived usefulness}

Perceived ease of use has a positive relationship with perceived usefulness. The existence of perceived ease of use in using technology will give consideration and decision to users to use or not use technology in an activity. In other words, perceived ease of use will encourage individuals to take advantage of the use of technology. Perceived ease of use has a positive and significant effect on perceived usefulness; the magnitude of the path coefficient is 0.42 with $\mathrm{p}$ value $<01$. That means that, the easier the technology is used, the higher the interest of individuals to use, from this side will give birth to perceived usefulness. The amount of contribution from perceived ease of use to perceived usefulness was $17.8 \%$. Pinho \& Soares [43]; Rauniar et al. [44]; Duvince \& Cheryl [45] state that perceived ease of use has a positive and significant effect on perceived usefulness. 


\subsection{Perceived ease of use has a positive and significant indirect effect on the attitude of using technology in entrepreneurship through perceived usefulness}

The ease of use of technology is one of the first aspects considered in the use of technology. Individuals before using technologies will pay attention to the difficulty or ease of use of technology. The easier technology is used will encourage individuals to be receptive to technology. Furthermore, Dickinger et al. [46] and Bruner \& Kumar [47] found that the easier an e-reader is to use, the better attitude towards its use. But what needs to be considered is the benefits that will be obtained by using technology. The higher the use of the e-reader perceived, the better the attitude towards the use of e-reader. A positive attitude will increase the intention to use the e-reader [46][48]. This study found that perceived ease of use has a positive and significant indirect effect on the attitude of using technology in entrepreneurship through perceived usefulness is $12.2 \%$. The path coefficient is 0.218 with a p-value <.01. Guritno and Siringoringo [12] perceived usefulness becomes a mediating variable; perceived ease of use indirectly affects the attitude of using technology in entrepreneurship through perceived usefulness. On the other hand, the contribution of the effect of perceived usefulness and perceived ease of use on the attitude of using technology in entrepreneurship is 55\%. This means that the attitude of using technology in entrepreneurship is influenced by other factors that are not examined by $45 \%$.

\section{Conclusion}

Technology acceptance of student entrepreneurship responded positively. Indicators of technology acceptance in entrepreneurship in this study are perceived usefulness and perceived ease of use have a positive and significant effect directly on the attitude of using technology. On the other hand, perceived ease of use has a positive and significant indirect impact on the attitude of using technology in entrepreneurship through perceived usefulness. The higher perceived usefulness and perceived ease of use will affect the attitude of using technology in entrepreneurship which is also higher.

\section{Implications and Limitation Study}

Implications of this study are: a) university leaders to facilitate the use of technology for students who join the entrepreneurship program, so that it has a positive effect on business continuity; b) university leaders provide education and instill awareness to students that technology is needed in entrepreneurship so that it will provide a positive perception in using technology; c) students who utilize technology in entrepreneurship are able to develop businesses for the better.

The limitation of this research is that it only examines two components of the TAM theory are perceived usefulness and perceived ease of use, while TRA theory about attitudes. And the subject in this study only on Semarang State University students who joined in the Indonesian Young Entrepreneurs Association. This is because the time to do research is limited. Recommend ate for further research to expand the study of TAM, researchers can adopt the perception of security variables and the perception of security using technology in business. 
While, from the TRA theory, researchers can expand research on trust. Future researchers can also combine the theory of TAM, TRA and TPB. Thus, research on TAM and TRA is more comprehensive.

\section{References}

[1] G. Wang, W. Dou, and N. Zhou, "Consumption attitudes and adoption of new consumer products: a contingency approach,” Eur. J. Mark., 2008.

[2] D. E. Rosen, J. E. Schroeder, and E. F. Purinton, "Marketing high tech products: Lessons in customer focus from the marketplace," Acad. Mark. Sci. Rev., vol. 6, pp. 1-17, 1998.

[3] P. Herbig and B. Hale, "Internet: the marketing challenge of the twentieth century," Internet Res., 1997.

[4] T. D. Nguyen and N. J. Barrett, "The adoption of the internet by export firms in transitional markets," Asia Pacific J. Mark. Logist., 2006.

[5] F. D. Davis, "Perceived usefulness, perceived ease of use, and user acceptance of information technology," MIS Q., pp. 319-340, 1989.

[6] M. L. Gillenson and D. L. Sherrell, "Enticing online consumers: an extended technology acceptance perspective," Inf. Manag., vol. 39, no. 8, pp. 705-719, 2002.

[7] J.-W. Moon and Y.-G. Kim, "Extending the TAM for a World-Wide-Web context," Inf. Manag., vol. 38, no. 4, pp. 217-230, 2001.

[8] A. L. Lederer, D. J. Maupin, M. P. Sena, and Y. Zhuang, "The technology acceptance model and the World Wide Web," Decis. Support Syst., vol. 29, no. 3, pp. 269-282, 2000.

[9] F. D. Davis, R. P. Bagozzi, and P. R. Warshaw, "User acceptance of computer technology: a comparison of two theoretical models," Manage. Sci., vol. 35, no. 8, pp. 982-1003, 1989.

[10] A. Susanto, Y. Chang, and Y. Ha, "Determinants of continuance intention to use the smartphone banking services," Ind. Manag. Data Syst., 2016.

[11] I. Bashir and C. Madhavaiah, "Consumer attitude and behavioural intention towards Internet banking adoption in India," J. Indian Bus. Res., 2015.

[12] S. Guritno and H. Siringoringo, "Perceived usefulness, ease of use, and attitude towards online shopping usefulness towards online airlines ticket purchase," Procedia-Social Behav. Sci., vol. 81, pp. 212-216, 2013.

[13] D.-K. Liou, L.-C. Hsu, and W.-H. Chih, "Understanding broadband television users' continuance intention to use," Ind. Manag. Data Syst., 2015.

[14] M. Fischbein and I. Ajzen, Belief, attitude, intention and behavior. Addison-Wesley, 1975.

[15] H. Hajer and A. Habib, "Factors of entrepreneurial intention of the public civil servant: Empirical evidence in the case of Tunisia," Int. J. Bus. Manag. Econ. Res., vol. 4, no. 1, pp. 673-687, 2013.

[16] K. Juhri and C. K. Dewi, "Kepercayaan Dan Penerimaan Layanan Mobile Money T-Cash Di Bandung Dengan Pendekatan Technology Acceptance Model (Tam)," Probisnis, vol. 10, no. 1, 2017.

[17] A. Mubiyantoro, "Pengaruh Persepsi Kegunaan, Persepsi Kemudahan Penggunaan, Persepsi Kesesuaian, dan Persepsi Risiko Terhadap Sikap Pengguna Mobile Banking (Studi Kasus di Bank BRI Kota Malang).” Universitas Brawijaya, 2013.

[18] K. Kanchanatanee, N. Suwanno, and A. Jarernvongrayab, "Effects of attitude toward using, perceived usefulness, perceived ease of use and perceived compatibility on intention to use Emarketing," J. Manag. Res., vol. 6, no. 3, p. 1, 2014.

[19] S. Soroa-Koury and K. C. C. Yang, "Factors affecting consumers' responses to mobile advertising from a social norm theoretical perspective," Telemat. informatics, vol. 27, no. 1, pp. 103-113, 2010 .

[20] Y. Yang, Y. Asaad, and Y. Dwivedi, "Examining the impact of gamification on intention of engagement and brand attitude in the marketing context," Comput. Human Behav., vol. 73, pp. 459-469, 2017.

[21] P. Moses, S. L. Wong, K. A. Bakar, and R. Mahmud, "Perceived usefulness and perceived ease of use: antecedents of attitude towards laptop use among science and mathematics teachers in 
Malaysia," Asia-Pacific Educ. Res., vol. 22, no. 3, pp. 293-299, 2013.

[22] M. Rizwan, S. M. Umair, H. M. Bilal, M. Akhtar, and M. S. Bhatti, "Determinants of customer intentions for online shopping: A Study from Pakistan,” J. Sociol. Res., vol. 5, no. 1, pp. 248 272, 2014.

[23] C. Antón, C. Camarero, and J. Rodríguez, "Usefulness, enjoyment, and self-image congruence: the adoption of e-book readers," Psychol. Mark., vol. 30, no. 4, pp. 372-384, 2013.

[24] M. Fishbein and I. Ajzen, "Belief, attitude, intention, and behavior: An introduction to theory and research," 1977.

[25] J. Zhao, S. Fang, and P. Jin, "Modeling and quantifying user acceptance of personalized business modes based on TAM, trust and attitude," Sustainability, vol. 10, no. 2, p. 356, 2018.

[26] B. Wu and C. Zhang, "Empirical study on continuance intentions towards E-Learning 2.0 systems," Behav. Inf. Technol., vol. 33, no. 10, pp. 1027-1038, 2014.

[27] M. Moslehpour, V. K. Pham, W.-K. Wong, and İ. Bilgiçli, "e-purchase intention of Taiwanese consumers: Sustainable mediation of perceived usefulness and perceived ease of use," Sustainability, vol. 10, no. 1, p. 234, 2018.

[28] T. Teo and J. Noyes, "An assessment of the influence of perceived enjoyment and attitude on the intention to use technology among pre-service teachers: A structural equation modeling approach," Comput. Educ., vol. 57, no. 2, pp. 1645-1653, 2011.

[29] A. M. Elkaseh, K. W. Wong, and C. C. Fung, "Perceived ease of use and perceived usefulness of social media for e-learning in Libyan higher education: A structural equation modeling analysis," Int. J. Inf. Educ. Technol., vol. 6, no. 3, p. 192, 2016.

[30] H. M. Jogiyanto, "Sistem informasi keperilakuan," Yogyakarta Andi Offset, 2007.

[31] G. Biehal, D. Stephens, and E. Curio, "Attitude toward the ad and brand choice," J. Advert., vol. 21, no. 3, pp. 19-36, 1992.

[32] M. A. Sallam and F. A. Algammash, "The effect of attitude toward advertisement on attitude toward brand and purchase intention," Int. J. Econ. Commer. Manag., vol. 4, no. 2, pp. 509-520, 2016.

[33] W.-H. Lee, C.-W. Lin, and K.-H. Shih, "A technology acceptance model for the perception of restaurant service robots for trust, interactivity, and output quality," Int. J. Mob. Commun., vol. 16, no. 4, pp. 361-376, 2018.

[34] H. Celik, "What determines Turkish customers' acceptance of internet banking?," Int. J. Bank Mark., 2008.

[35] V. S. Chau and L. W. L. C. Ngai, "The youth market for internet banking services: perceptions, attitude and behaviour," J. Serv. Mark., 2010.

[36] T. C. E. Cheng, D. Y. C. Lam, and A. C. L. Yeung, "Adoption of internet banking: an empirical study in Hong Kong," Decis. Support Syst., vol. 42, no. 3, pp. 1558-1572, 2006.

[37] J.-S. Chiou and C.-C. Shen, "The antecedents of online financial service adoption: the impact of physical banking services on Internet banking acceptance," Behav. Inf. Technol., vol. 31, no. 9, pp. 859-871, 2012.

[38] B. Pynoo, J. Tondeur, J. Van Braak, W. Duyck, B. Sijnave, and P. Duyck, "Teachers' acceptance and use of an educational portal," Comput. Educ., vol. 58, no. 4, pp. 1308-1317, 2012.

[39] Q. Zhao, C.-D. Chen, J.-L. Wang, and P.-C. Chen, "Determinants of backers' funding intention in crowdfunding: Social exchange theory and regulatory focus," Telemat. Informatics, vol. 34, no. 1, pp. 370-384, 2017.

[40] F. Weng, R.-J. Yang, H.-J. Ho, and H.-M. Su, "A TAM-based study of the attitude towards use intention of multimedia among school teachers," Appl. Syst. Innov., vol. 1, no. 3, p. 36, 2018.

[41] H. Mohammadi, “A study of mobile banking usage in Iran,” Int. J. Bank Mark., 2015.

[42] T. Teo and M. Zhou, "Explaining the intention to use technology among university students: a structural equation modeling approach," J. Comput. High. Educ., vol. 26, no. 2, pp. 124-142, 2014.

[43] J. C. M. R. Pinho and A. M. Soares, "Examining the technology acceptance model in the adoption of social networks," J. Res. Interact. Mark., 2011.

[44] R. Rauniar, G. Rawski, J. Yang, and B. Johnson, "Technology acceptance model (TAM) and 
social media usage: an empirical study on Facebook," J. Enterp. Inf. Manag., 2014.

[45] D. Z. Dumpit and C. J. Fernandez, "Analysis of the use of social media in Higher Education Institutions (HEIs) using the Technology Acceptance Model," Int. J. Educ. Technol. High. Educ., vol. 14, no. 1, pp. 1-16, 2017.

[46] A. Dickinger, M. Arami, and D. Meyer, "The role of perceived enjoyment and social norm in the adoption of technology with network externalities," Eur. J. Inf. Syst., vol. 17, no. 1, pp. 4-11, 2008.

[47] G. C. Bruner II and A. Kumar, "Explaining consumer acceptance of handheld Internet devices," J. Bus. Res., vol. 58, no. 5, pp. 553-558, 2005.

[48] S. Kulviwat, G. C. Bruner II, A. Kumar, S. A. Nasco, and T. Clark, "Toward a unified theory of consumer acceptance technology," Psychol. Mark., vol. 24, no. 12, pp. 1059-1084, 2007. 